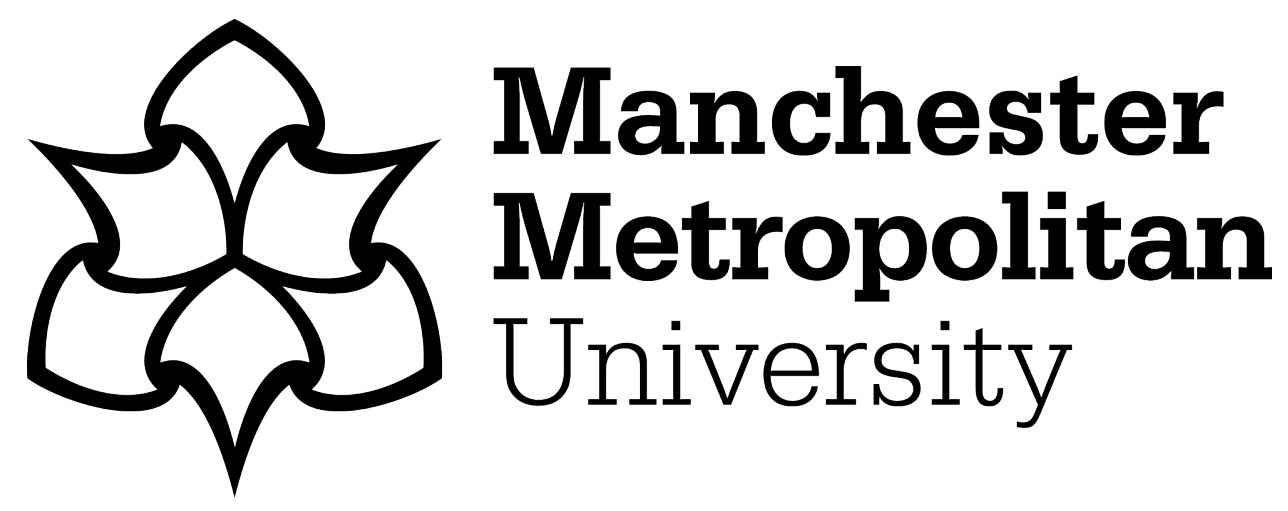

Grail, Julie, Mitton, Catherine, Ntounis, Nikos ORCID logoORCID: https://orcid.org/0000-0003-2517-3031, Parker, Cathy ORCID logoORCID: https://orcid.org/0000-0002-8072-269X, Quin, Simon, Steadman, Chloe ORCID logoORCID: https://orcid.org/0000-0003-1132-3502, Warnaby, Gary ORCID logoORCID: https://orcid.org/0000-0002-6696-6671, Cotterill, Emily and Smith, Diane (2020) Business Improvement Districts in the UK: A Review and Synthesis. Journal of Place Management and Development, 13 (1). pp. 73-88. ISSN 1753-8335

Downloaded from: https://e-space.mmu.ac.uk/624418/

Version: Accepted Version

Publisher: Emerald

DOI: https://doi.org/10.1108/JPMD-11-2019-0097

Please cite the published version 


\title{
Business Improvement Districts in the UK: A Review and Synthesis
}

\begin{abstract}
Purpose - The purpose of this paper is to review the development and current position of Business Improvement Districts (BIDs) in the UK, drawing on the content within A State-of-the-Art Review of Business Improvement Districts in the UK: Setting the Agenda for Policy, Practice and Research, commissioned by The BID Foundation, and produced by members of the Institute of Place Management.
\end{abstract}

Design/Methodology/Approach - The paper is divided into seven main sections. The first section defines the concept of BIDs, outlines their process of establishment, and provides a brief critique of BIDs from the academic literature. Second, the process of introducing BIDs into the UK is discussed. Third, the different types of BIDs that currently exist are detailed. The fourth section outlines the development of BIDs since their introduction in 2004. Fifth, an analysis of BID ballots is provided, involving details of ballot results, demonstrating a general improvement as BIDs develop over time. The sixth section comprises a discussion of unsuccessful ballots and BID terminations. The paper concludes with a brief analysis of issues facing BIDs in the UK, looking into the future.

Findings - The paper contains three main empirical contributions: first, a numerical analysis of the different types of BIDs in the UK; second, a timeline of their development from 2005-2018; and third, a statistical analysis of BID ballot results over this period, with an indication of the numbers of unsuccessful ballots and BID terminations.

Originality/value - This paper provides the first comprehensive overview of BIDs in the UK detailing development and performance (e.g. ballot results) in the 15 years since their introduction.

Keywords - Business Improvement Districts; BIDs; UK; BID Types; BID Ballot; BID failure

Paper type - General Review 


\section{Introduction}

Following the commencement of the first Business Improvement District (BID) in Kingston-uponThames in January 2005, BIDs have become an important part of the formal infrastructure of place management in the UK, as well as being significant organisers of events/festivals - of all kinds, from cultural festivals to Christmas markets - within their spatial jurisdictions. However, notwithstanding their increasing significance, there remains a paucity of academic literature concerning the subsequent development of BIDs. The aim of this paper is to address this lacuna by reviewing the development of BIDs over the last 15 years, to consider how they have become an integral element of place management practice in the UK. Indeed, there are now over 300 such organisations operational across the length and breadth of the UK, most of whom will be responsible to some degree for planning and implementing events - and other place-based initiatives - within their locale.

This paper draws on information detailed in the recent State-of-the-Art Review of Business Improvement Districts in the UK (see Cotterill et al., 2019) commissioned by The BID Foundation. The extant literature on BIDs is somewhat fragmentary and limited in scope - as well as spread across a number of academic disciplines. Consequently, there is no one 'definitive' source outlining how the BID concept has become the pre-eminent town/city centre management organisational mechanism in the UK. The 'state-of-the-art' review, from which this paper is drawn, seeks to address this deficiency, by providing a comprehensive overview of BIDs development and diffusion across the UK, which analyses BID ballot results (and details the means by which relevant data - which also inform this paper - were generated), and concludes by identifying an agenda for policy, practice and research within the context of BIDs.

We begin by defining BIDs and propose a conceptual model of the life cycle of an individual BID. The events leading to their introduction, initially into England and Wales and subsequently into Scotland and Northern Ireland, are outlined. The paper then discusses the different types of BIDs that currently exist, and analyses their development trajectory, from 2005 to the end of 2018 (the timeperiod covered by the 'state-of-the-art' review, when 303 BIDs were in existence), introducing the notion of a possible BID industry life cycle. We next analyse the results of the ballots by which the mandate for individual BIDs is established (and periodically renewed through re-ballots). Whilst the story of BID development in the UK is generally one of success, there are some locations where ballots/re-ballots have been unsuccessful. We thus turn our attention to analysing the reasons for such 'failure' of certain BIDs. The paper concludes by considering how BIDs may develop into the future, in light of the changes currently impacting traditional retail centres.

\section{What are BIDs? Definitions, processes, and critiques}

Whilst there is no single definition of BIDs over which there is consensus (Hoyt, 2004; Ward, 2007), Ward (2007: 658) states, "it is possible to discern some generally agreed characteristics", including:

- A mechanism (in the form of a levy) whereby relevant property/business owners elect to make a collective contribution (for a specific period of time) to secure private capital to fund activities within a designated commercial area in order to improve its attractiveness;

- The existence of a clearly delineated spatial remit;

- A partnership modus operandi between public and private sector actors. 
The BID concept per se is generally made possible by act of consent by the local authority(ies) for the area in which it will operate (see Briffault 1999, Local Government Act, 2003). Once such an act of consent is granted, Ward (2007) further explains that the generic process of establishing an individual BID involves the canvassing of local business opinion as to its desirability, followed by a vote on whether to establish the BID. Assuming this vote is positive, a management structure comprising representatives of relevant stakeholder constituencies is created, and a strategy developed. Ward summarises the different types of strategies that can be developed (and reviewed on a regular basis) as follows:

- Physical infrastructure - i.e. capital improvements, economic development, area maintenance;

- Promotional infrastructure - i.e. marketing to place users and other consumers, and policy advocacy;

- Surveillance infrastructure - i.e. public space regulation and security.

This generic process can be conceptualised as a number of stages in a 'life cycle' process of the development and (possible) cessation of an individual BID, namely: Interest, Feasibility, Ballot, Delivery, and Renewal or Disband, which is outlined in Figure 1 below:

\section{INSERT FIGURE 1 HERE}

At the Interest stage, a group of potential levy payers in a location spend time building their knowledge and understanding of the BID concept per se. This stage provides an opportunity to gauge interest in the principle of a BID, perhaps identify possible priorities of action, and establish the proposed boundary of the BID.

Assuming there is enough initial interest at the Feasibility stage, the potential levy payers need to develop a more extensive, in-depth analysis of the issues facing the area. This involves working out how the BID might be operationalised (i.e. establishing the levy rules, and the priorities the BID will focus on), in addition to developing a sufficient critical mass of support for the BID. At this and subsequent stages, a BID consultant may also be engaged to help with the activities detailed above (a number of companies undertake feasibility and development support for BIDs, guiding them at first and renewal ballots, as well as providing ongoing support and project management, or in some cases a full BID management service throughout the life cycle). Depending on the results of the feasibility study, the BID may begin a consultation process with stakeholders on its project delivery, before finalising the proposals ahead of a ballot.

At the Ballot stage, a suitable proposal should have been developed, and enough support engendered, to gain at least $50 \%$ of 'yes' votes (by both number of levy payers and the rateable value they account for) to support the BID going ahead in the locale. If the ballot is successful, the BID can then be established and the Delivery stage begins. Here, the business plan constituting the BID's mandate to operate is implemented. As noted above, the activities included in business plans could relate to factors such as improving physical infrastructure, enhancing security within the area, and marketing/promotion of the area.

Near the end of its typical five-year term, the BID may seek to continue its mandate through another ballot, putting forward a new business plan for approval (or not, as the case may be) by levy payers. 
If successful, the BID begins to implement this new business plan. However, sometimes BIDs may not get this Renewal mandate because of failure in this ballot, or, in a very small number of cases, may Disband mid-term, or not seek re-election.

The generic process outlined above, however, masks significant variations in detail, with differences in specific regulation across - and indeed within - different countries, and in some cases, localities (Hoyt and Gopal-Agge, 2007; Ward, 2007). For example, within the UK, there are some specific differences in BID regulation in Scotland and Northern Ireland, when compared to England and Wales. Specifically, in Scotland and Northern Ireland, there is a turnout threshold for BID ballots, where at least $25 \%$ of eligible levy-payers must vote. This was an issue raised when BIDs were first introduced in England, but was rejected by government as it was believed "thresholds can have perverse consequence", with people seeking to use their vote tactically (New Local Government Network, 2003; online). However, the UK government did encourage BIDs to design schemes that would maximise turnout in ballots. Indeed, it was keen to ensure a "flexible legal framework", which enabled each BID to be different (dependent on particular circumstances), and which was also aimed at improving the local business environment (ibid). Likewise, Steel and Symes (2005: 325) emphasise that there "is certainly no 'one size fits all' approach" to BID creation and governance, further suggesting that this flexibility is one of the "strong points" (ibid) of BIDs.

However, BIDs have been the subject of some criticism in the academic literature; De Magalhães, for instance, states that, "the apparent success of BIDs as suggested by their rapidly expanding numbers should not obfuscate the complex and contentious issues that are associated with them" (2014: 917). He further identifies three main issues emerging from the debates that have occurred about the role of BIDs as public realm governance mechanisms. First, the extent to which BIDs represent the privatisation of the governance of public spaces (De Magalhães, 2014 - see also Steel and Symes, 2005). Indeed, BIDs could be regarded as an aspect of the increasing privatisation in urban development policy, where they represent a partial transfer of the delivery of public services to private sector actors. Critics see this increased involvement of the private sector in urban management as part of a trend towards the greater privatisation of public space (see Minton, 2009), with BIDs complicit in the over-regulation of public space, through for example, the provision of supplemental security and maintenance services (Hoyt and Gopal-Agge, 2007).

Second, there is debate concerning the democratic accountability in the consequent decisions involving the public realm (De Magalhães, 2014). Steel and Symes (2005: 326), for example, articulate a range of "potential problems with BIDs", in particular relating to their democratic accountability, operational factors, such as "who pays how much and who gets to decide how the money raised is spent" (ibid: 327), and, linked to this, voting structures within individual BIDs. Similarly, Hoyt and Gopal-Agge (2007: 951) are concerned with the extent to which BIDs may be "less than democratic in their structure and operation".

The third issue relates to the potential exacerbation of interlocal inequalities in the provision of public services (De Magalhães, 2014). Here, ability to pay may become a determinant of both quantity and quality of services provided, arising from the inevitable concentration of efforts and resources generated from levy payments within BIDs' spatial boundaries (Hoyt and Gopal-Agge, 2007). Another set of related criticisms surround the inequalities that BIDs may produce, such as the unforeseen consequences of associated "indirect costs" or "spillover effects"; in other words, the displacement of crime and other problems (such as the provision of support for homeless people) to areas outside their service boundaries (Hoyt and Gopal-Agge, 2007: 951). 
However, despite this critical perspective from some academic sources, in the UK BIDs have become an important means by which urban space is managed. Indeed, Hemphill et al. (2014: 681) state that BIDs "have become the favoured model for cost-effective local service delivery in the UK" since their introduction in the early 2000s. We now outline the process by which this introduction occurred.

\section{Introducing BIDs into the UK}

Peyroux et al. (2012) describe BIDs as a 'travelling concept'; and we will now explore their journey to establishment within the UK context. From their origins in North America and Canada (see Briffault, 1999), BIDs have been adopted in various countries, including New Zealand, South Africa, the Netherlands, Germany, and - of particular relevance to our paper - the UK. Ward notes the countries that have adopted BIDs most readily are those most often associated with neoliberal reforms in terms of governance, suggesting that in these countries BIDs are presented "as solutions to the failures of past policies and practices of the state" (2007: 667).

Indeed, it could be argued the introduction of BIDs into the UK was seen by many as a means of overcoming some of the perceived deficiencies in alternative types of urban place management initiatives, particularly town centre management (TCM) schemes. Peel and Lloyd (2008: 195), for instance, view TCM as a stepping-stone towards BIDs, describing TCM as "a precursor to what works". Since the appointment of the UK's first 'town centre manager' in 1987 (Wells, 1991), the TCM concept grew through the 1990s, with approximately 230 schemes in existence by 1999 (Association of Town Centre Management [ATCM], 1999). By the time legislation to enable BIDs was passed, it was suggested there were up to 450 town centre managers and TCM schemes operative in the UK (Hollins, 2004). However, a key issue with TCM was the voluntary nature of participation and funding (see Medway et al., 1998, 1999, 2000), which led to concerns regarding its sustainability in many locations. Warnaby and Medway (2006), for example, suggest that the ability of TCM schemes to plan and implement effective marketing activities was arguably compromised by funding discontinuity and the related issue of 'free-riding' (i.e. the majority of urban stakeholders who enjoy the benefits arising from TCM activities do not typically contribute to them). BIDs, therefore, were regarded by many as a means of overcoming some of the inherent problems arising from the essentially voluntary nature of stakeholder participation in TCM.

From the early-1990s onwards, there was increasing interest in developing BIDs in the UK (see ATCM, 1997; Shutt et al., 1999). The Corporation of London, for example, commissioned a report that looked at the experience of New York BIDs and how this might be applied in London (Travers and Weimar, 1996). This initially led to a modification to the London Local Authorities Bill (1997) supporting the introduction of BIDs within London; however, this addition was later withdrawn following concerns from some boroughs (Hansard, 1997). Following this, Lord Jenkin of Roding introduced a Private Members Bill in 1997, drawing on work undertaken by the ATCM and the Association of London Government, to allow BIDs to set-up across the UK (Hansard, 1997); yet, this bill was also unsuccessful.

It was arguably the renewed focus of urban policy introduced by the New Labour Government that ultimately led to the introduction of BIDs in the UK (Ward, 2011). To develop effective regulations, and to further support the development of BIDs in England, the newly established department of the Office of the Deputy Prime Minister (ODPM) commissioned the (then) Association of Town Centre Management to lead a National BID Pilot Project. This project involved first putting out a call for potential pilot locations, which subsequently received over 100 expressions of interest (Ward, 2011). Twenty-two locations were selected to become part of the pilot, and representatives from these places were then taken on a study tour to see US BIDs in operation, attended workshops and 
received briefings, and were supported through the aforementioned stages of BID development (as detailed in Figure 1 above). The pilot towns and ATCM worked with ODPM to draft regulations that worked in practice. Also feeding into the development of the regulations was The Circle Initiative: a £4.6m Single Regeneration Budget-funded pilot scheme in five areas of central London, which was later passed over to the London Development Agency ${ }^{1}$.

In 2001, a government White Paper - Strong Local Leadership: Quality Public Services - set out the principles behind the proposed legislation to allow the operation of BIDs in England and Wales, emphasising flexibility in order to permit the development of individual BIDs to be responsive to local circumstances, and aimed at improving the local business environment. Indeed, BIDs were promoted by Nick Raynsford (the then Minister of State in ODPM) as a "model for economic renewal" (NLGN, 2003: online). The primary legislation to enable BIDs in England and Wales was included in the Local Government Act 2003, with subsequent detailed regulations outlining procedures for their establishment and management introduced through the Business Improvement Districts (England) Regulations 2004 (SI2004/2443) and in Wales, through similar regulations published in 2005. Whilst a localised statutory instrument is in place for Wales, the legislative detail is the same as for England.

In Scotland, on the other hand, the necessary legislation to establish BIDs came into effect in 2007, initiated by the Scottish Government, primarily as a regeneration tool for town and city centres. A group of pathfinder BIDs (with the objective of testing the BID concept and its applicability in Scotland) were supported via 'BIDs Scotland': an in-house government department, which at the time was charged with setting up BIDs. Seed-corn funding of $£ 20,000$ per location was subsequently issued and this government-funded programme ran until 2018, until it was then disbanded and recreated as Scotland's Improvement Districts, run as part of the Scotland's Town Partnerships. BIDs were thereby introduced in Scotland through various pieces of legislation (i.e. Part 9 of The Planning etc. (Scotland) Act 2006; Business Improvement Districts Levy Order 2007; The Business Improvement Districts (Scotland) Regulations 2007; The Business Improvement Districts (Ballot Arrangements) (Scotland) Regulations 2007; The Business Improvement Districts (Scotland) Amendment Regulations 2007 No. 510; and The Business Improvement Districts (Scotland) Amendment Regulations 2008 No. 359). The main differences in the Scottish BIDs legislation - when compared to that of England and Wales - is the need to achieve a $25 \%$ turnout in ballots, in addition to the opportunity to include property owners and occupiers (who are the sole constituency in England and Wales) as levy payers.

It was not until 2013 and 2014 that BIDs were introduced in Northern Ireland, with The Business Improvement Districts Act 2013, The Business Improvement Districts (General) Regulations (Northern Ireland) 2014, and The Business Improvement Districts (Miscellaneous) Regulations (Northern Ireland) 2014. The primary legislation is similar to that in Scotland as it includes a provision for a minimum 25\% ballot turnout. However, as in England and Wales, the BID levy is payable by occupiers only.

\section{Types of BIDs}

As noted above, BIDs were designed to be sensitive to the needs of individual groups of businesses (particularly those property occupiers who are liable for the BID levy) and the specific locations in which they exist, rather than constituting a prescriptive 'one size fits all' approach. Consequently,

\footnotetext{
${ }^{1}$ https://www.london.gov.uk/what-we-do/business-and-economy/supporting-business/aboutbusiness-improvement-districts)
} 
this can make comparison and evaluation of BIDs somewhat complicated, and it is thus important to utilise appropriate criteria for categorising the different types of BIDs that exist in the UK. Here, two methods to group - or classify - BIDs are used: first, we utilise the precise legal form of the BID as a means of classification; and second, we use BIDs' own self-definition of the type of BID they are.

\section{Legal definitions}

The legal classification approach identifies four different categories of BIDs: property-occupier BIDs, property-owner and occupier BIDs, property-owner BIDs, and cross-borough BIDs.

The vast majority (98.3\%) of BIDs in the UK are property-occupier BIDs, where the business that occupies the property in the BID area pays the levy (i.e. the eligible ratepayer). Such BIDs vary in size and scale, as they represent a diversity of places. The smallest BID, in terms of turnover, is currently $£ 17,500$ and the largest is $£ 4,100,000$. The mean average turnover is $£ 393,386$ but the standard deviation is 445,171 , thereby demonstrating that a 'typical' property-occupier BID is a misnomer.

The other legal types of BIDs either constitute a handful of examples (i.e. property-owner, and property-owner and occupier BIDs), or only exist in theory (i.e. cross-borough BIDs). Since 2014 in London, BIDs can be established where it is property owners only who pay the BID levy. However, in line with the underpinning Business Rate Supplement legislation, the property-owner BID has to be 'overlaid' on a property-occupier BID. ${ }^{2}$ Currently there are only three locations with property-owner BIDs: the New West End Property BID, Leicester Square, and St James \& Piccadilly. Recently, in 2018, the Business Rate Supplement has been extended to four other English Combined Authority areas so the number of this type of BID may grow in future. The option exists in Scottish legislation to apportion the levy charge between owners and occupiers, as long as this is stated in the levy rules, before the BID is established. By the end of 2018, there existed two Scottish BIDs that have actively engaged property-owners in this way: Inverness City and Clacksfirst.

In 2013, the English Regulations relating to BIDs were amended to enable 'cross-borough' BIDs. ${ }^{3}$ This title is perhaps slightly misleading in that BIDs can (and do) operate across local authority boundaries in all country jurisdictions, irrespective of this regulation amendment (see, for example, Segensworth and Waterloo). The 2013 amendment merely allows for the combination of two or more local authority areas (in England) into one set of BID arrangements (i.e. one ballot or one levy collection/budget). However, despite this change in the regulations, by the end of 2018 no location had used this legislation.

\section{Self-definitions}

As noted above, whilst in legal terms there are four forms of BIDs, the vast majority of BIDs are property-occupier BIDs, which are very heterogeneous because, in practical terms, the flexibility in the legislation allows BIDs to cover vastly different spatial areas and include (or exclude) different sizes and types of businesses as levy payers. Consequently, it has become common practice for property-occupier BIDs to self-identify depending on the dominant land-use within their geographical area and the subsequent levy payers. This self-identification of BID type draws from the following categories: Town centre; Commercial; Industrial; Leisure; Retail; Tourism; and Other BIDs.

By far the largest of these self-identified categories is Town centre BIDs (78.7\% - 235 BIDs), which cover some or all of the core commercial area of a town/city centre. The second largest category is

\footnotetext{
${ }^{2}$ See http://www.legislation.gov.uk/uksi/2014/3204/contents/made

${ }^{3}$ See http://www.legislation.gov.uk/uksi/2013/2265/contents/made
} 
Industrial BIDs (10.3\% - 25 BIDs), which are usually found in a defined industrial estate/area, or a designated business park. Although they vary in scale, generally they have fewer levy payers than town centre BIDs and have a smaller budget, and they can be very focused over a relatively small area. Smaller numbers of different types of BIDs also exist, including the following:

- Commercial BIDs (9 BIDs) - focused on commercial properties and offices in urban areas where the dominant land-use within the BID area is commercial, e.g. Team London Bridge.

- Tourism BIDs (9 BIDs) - usually spread over a larger geographical area. Unlike other types of BIDs, some tourism BIDs exclude certain types of levy payers, meaning that they are more sector-focussed than place-focused, e.g. English Riviera Tourism BID, Wight BID, and Yorkshire Coast BID.

- Leisure BIDs (4 BIDs) - focused on leisure and the evening economy. Similar to commercial BIDs, these BIDs are merely reflective of their dominant activity/use within their jurisdictional area, e.g. Birmingham Westside around Broad Street, Heart of London's Leicester Square, to Piccadilly Circus BID and All in Sauchiehall, Glasgow.

- Retail BIDs (4 BIDs) - whilst located in town/city centres, these BIDs have a more specific retail focus, reflecting their spatial remit within the retail core of the place in question, e.g. Retail BID Birmingham focuses the city's retail core and adjoins other BIDs that cover commercial and leisure areas of the city.

- Other (6 BIDs) - which do not fall into any of the above categories, perhaps because they focus on more than one business aspect within their respective boundaries, such as Liverpool Retail and Leisure BID. Furthermore, other BIDs are working towards promoting local products for the food and drink sector (e.g. East Lothian Food and Drink), or by focusing predominantly on placemaking initiatives within a broader geographical area (e.g. North Notts BID).

\section{The growth of BIDs in the UK}

The trajectory of growth in the number of BIDs in the UK since their inception in 2005 is shown in Figure 2 below (not including BIDs scheduled to begin operation in 2019 after successful ballots in 2018 , and Irish BIDs). As noted in the introduction, the cumulative total of operational BIDs in the UK, as of the $31^{\text {st }}$ December 2018, was 303.

\section{INSERT FIGURE 2 HERE}

The graph above (Figure 2; also see Cotterill et al., 2019) highlights a continuous growth of BIDs since their inception, manifested by a steady increase in new BIDs almost every year. From 2005, the first year that BIDs were operational in the UK (when 14 BIDs were established), the number of new BID starts per year has fluctuated between 10 (in 2010) and 43 (in 2016). This growth may reflect government initiatives, such as seed-corn funding and other programmes to encourage BID formation. The graph also displays negative figures from 2013-2018, which illustrates BIDs that have either failed at their renewal ballot or ceased operations mid-term (discussed later in this paper).

Despite the higher number of BID starts since 2012, recently, the number of new BID starts per year shows signs of declining. After the peak of 43 new BID starts in 2016, there were 31 new BID starts in 2017, and 28 in 2018. Notwithstanding earlier occasions where new BID starts in a particular year 
were less than the previous year (i.e. in 2007, 2009-2010, 2013, and 2015), the fact that the number of new BID starts has been in decline since 2016 could suggest there is a trend towards decelerating speed of growth.

Another contributory factor in the current slow-down of growth in BID starts could be an increasing number of BIDs that are not successful at first ballot (this notion of BID 'failure' is further discussed later in this paper). To demonstrate, since 2016, figures drawn from Cotterill et al. (2019) suggest there were 10 failures at initial ballot, with a further BID never established despite a successful ballot result because of a legal challenge.

In order to better understand the current status of the UK BIDs industry, we can arguably draw on 'product life cycle' theory from the marketing discipline. This theory suggests that product offerings move through a sequential developmental pattern, including the following four stages: Introduction, Growth, Maturity, and, potentially, Decline (see Rink and Swan, 1979). Applying this concept to the context of the UK BIDs industry more broadly (in contrast to the discussion of life cycle stages of an individual BID highlighted earlier), the Introduction stage (following the pre-2005 initial development of BIDs and BIDs pilot scheme) took place from 2005 to 2010-11. This stage saw a gradual increase in new BID starts each year (as well as a handful of renewal ballots where the earliest BIDs achieved renewal). The Growth stage, from 2011-12 to 2016, experienced significantly higher numbers of new BID starts annually (albeit not in continuous annual increases), alongside much greater numbers of successful renewal ballots. One contributory factor relating to renewal ballots here was the shorter first terms of the first BIDs, usually from 2-3 years (as opposed to the five-year terms that are now the norm). As noted above, the pace of expansion has stalled somewhat since 2016, indicating that, whilst still growing, the BIDs industry is possibly entering the Maturity stage of the lifecycle.

Product life cycle theory also implies that life cycles can be extended almost indefinitely and, in the case of BIDs, this could potentially be seen, at the industry level, in the development of more niche 'sectoral' BIDs, as discussed above (e.g. Industrial, Tourism, and Leisure-oriented BIDs). In addition, new BIDs may start to form in smaller locations, as was the case in Scotland (Institute of Place Management, 2018). However, across the UK as a whole, no such trend relating to BID formation accelerating in smaller locations can be established. In 2005, there was a cohort of 14 'Big BIDs' established, with an annual levy of over $£ 629,000$ and an average number of over 500 hereditaments (i.e. the business units liable for non-domestic rates in the BID area). Since 2005, more BIDs have been established and this has included smaller BIDs; so the average annual levy and the average number of hereditaments has always been less than those associated with the first cohort of Big BIDs. However, Table 1 below shows there is no clear trend that the average annual levy or the number of hereditaments is falling.

\section{INSERT TABLE 1 HERE}

\section{BID ballot performance}

A fundamental factor determining the ability to set up (and renew) a BID, is success in the initial ballot of proposed levy-payers (and subsequent renewal ballots of this constituency to enable the BID's mandate to continue). Thus, any discussion of the development of BIDs perforce arguably has to analyse ballot results. Therefore, Figure 3 below indicates the results of BID ballots (for all types of BIDs) in first, second, third, and fourth terms, in relation to voter turnout, the percentage of levy- 
paying businesses voting 'yes', and the rateable value (RV) of businesses voting 'yes' in favour of establishing a BID.

\section{INSERT FIGURE 3 HERE}

To test for statistically significant differences between first and subsequent ballots, ANOVA ${ }^{4}$ was used to ascertain any significant differences in ballot results across three terms (see Cotterill et al., 2019). The mean values (in \%) and standard deviation (s.d.) of voter turnout, 'yes' votes by number of businesses, and 'yes' by rateable value votes for the BIDs, which have been through three terms, are displayed in Table 2 below.

Results from the ANOVA test showed that there was a statistically significant difference in voter turnout across the terms, with higher turnout in terms two and three ${ }^{5}$. There was also a statistically significant difference in 'yes' votes with a higher percentage of 'yes' votes in term three ${ }^{6}$. Similarly, the difference in 'yes' votes by rateable value is also statistically significant, with a higher percentage of 'yes' votes in term three'. The standard deviations (s.d.) are relatively low, meaning that most ballot results are close to the mean values (averages) presented.

\section{INSERT TABLE 2 HERE}

Comparing ballot results over three terms across the UK, all ballot results are improving. In general, as a BID is elected, and subsequently re-elected, more levy payers actually vote, and vote 'yes' by both majority of those voting and rateable value, indicating that generally local levy payers are more aware of their BID, and more supportive of them, over time. These figures refer to all BIDs across the UK; however, Cotterill et al. (2019) disaggregate this analysis by the constituent countries of the UK, where there is some variation between different ballot results. For example, in Scotland, 'yes' votes, by both number of businesses and rateable value, drop in the second ballot, whereas both increase across the UK as a whole. Previous research into Scottish BIDs (Institute of Place Management, 2018) found a significant difference in 'yes' votes between English (excluding London) and Scottish BIDs at second ballot, and suggested that Scottish BIDs "subject to a second term may suffer from a loss of momentum and confidence from businesses" (ibid: 7). Nevertheless, those Scottish BIDs going into a third term are more successful, in ballot terms, and are close to the UK average.

In general, therefore, BIDs are more popular as their terms progress, which signifies that they are perceived as making a positive contribution to the levy payers and locations that they serve.

However, whilst the story of the development of BIDs in the UK is generally one of success, there are a relatively small number of locations where ballots have been unsuccessful (either at the initial ballot, or at a subsequent renewal ballot). We now move to discuss such BID 'failure' in ballots and

\footnotetext{
${ }^{4}$ ANOVA tests are used to determine whether samples from two or more groups come from populations with equal means; in other words, do the group means differ significantly (Hair et al, 2006).

${ }^{5}(\mathrm{~F}(2,74)=4.18, \mathrm{p}=0.019)$

${ }^{6}(\mathrm{~F}(2,106)=7.37, \mathrm{p}=0.001)$

${ }^{7}(F(2,86)=20.62, p<0.001)$
} 
also other scenarios, which have resulted in either non-commencement of a BID, or termination mid-term or at term-end.

\section{Unsuccessful ballots and BID terminations}

It is difficult to be definitive as to the number of locations where BID 'failure' (however manifested) has occurred, especially relating to failure at initial ballot (i.e. because of a lack of evidential data sources as time progresses). However, based on a range of secondary sources generated via internet searches (see Cotterill et al., 2019), our most accurate estimate of the number of instances of the different types of unsuccessful ballot and termination, are shown in Table 3.

\section{INSERT TABLE 3 HERE}

The data suggests there have been a total of 74 unsuccessful ballot results, with a further 14 locations that either once had a BID but where this BID no longer operates, or where there has never been an operational BID despite having a successful ballot result. Analysis of the sources used (see Cotterill et al., 2019, for a detailed discussion), suggests that in general terms, BIDs that are not established have not engaged significantly with levy payers, either to explain the BID concept, agree the levy details, and/or formulate the business plan. Whereas, those that are not renewed have not delivered sufficient value to a significant number of their levy payers.

Those BIDs that disband may do so mid-term or at the end of a term. The most likely cause of a BID disbanding (at mid-term or end of term) are concerns from levy payers about the operation/delivery of the BID. However, some BIDs have also disbanded at the end of a term because stakeholders have identified a more suitable structure to carry on the work of the BID. BIDs that have not gone out to ballot for a further term have sometimes had legitimate reasons for doing so; reasons that, in one way or another, represent the interests of the levy payers. These may be because the BID is no longer needed as a structure for collaboration (as in the case of Southern Cross), or that the geographical focus of the BID changes (as in the case of Torquay and Paignton). In other instances, it is because the BID has not delivered adequate benefits to enough levy payers, and the levels of negative feedback have suggested a renewal ballot is unlikely to be successful.

\section{Conclusion: Fundamental issues facing BIDs in the UK}

In this paper, we are - to use Hollander's (1986) analogy in relation to the study of retailing - looking in the 'rearview mirror' to trace the development of BIDs in the UK and the current position of the UK BID 'industry'. However, Hollander also notes that taking a historical perspective can inform future industry development, suggesting that looking in "[a] rearview mirror might help us drive forward" (ibid: 7). Thus, we conclude this paper with a brief assessment of the issues facing BIDs in the UK both now and into the future, linking to areas for further research.

As mentioned previously (and notwithstanding some of the issues relating to BID 'failure' described above), the story of the development of BIDs in the UK is generally one of success. As far as individual BIDs are concerned, this is often a result of dynamic individuals driving the process, and if this success trajectory is to be maintained as the BID industry potentially 'matures', then developing and promulgating effective governance structures and mechanisms more broadly within individual BIDs should be a priority. Given the difficulties faced in finding information about some ballot results 
to inform the 'state-of-the-art' review, fully professionalising management arrangements in BIDs would help ensure the existence of accurate and appropriate contractual documentation. Such documentation includes business plans, levy rules and legal agreements (e.g. with local authorities) so as to avoid any ambiguity - and potentially, conflict - in terms of activity scope and performance. This would also facilitate performance management and evaluation. As suggested earlier, if the BID 'industry' is indeed maturing, then it is important to ensure Boards of Directors have the requisite skills and competencies, and a very clear understanding of the responsibilities of BID governance. Indeed, the topic of BID governance is one that would benefit from further, more detailed research inquiry.

Moving beyond individual BIDs to consider broader contextual factors that may impact on their future development - and given the fact that $78.7 \%$ of BIDs are 'town centre' BIDs - then the changing nature of retailing and resultant impact on traditional retail centres (see Millington et al., 2015; Millington et al., 2018), will inevitably impact on BIDs. This is because, whilst many BIDs have a diverse business base, retail is often fundamental to this base because of its importance to urban economies. The changes that are happening to town centre retailing are well documented (see also, Parker et al., 2017), and it is inevitable they will have an impact not only on the potential funding base for many BIDs, but also the activities within the business plans which essentially constitute their mandate to operate. Arguably, it will be those BIDs that are inclusive of all businesses types, and can reach out to other important groups, such as residents, will be the ones that are better able to navigate successfully through this changing environment. Detailed analysis of the activities contained in BIDs' business plans (and how these activities develop over time) would be another fruitful area for further research.

An important aspect in determining future effectiveness will be the relationship between BIDs and Government. In this paper, we have highlighted the role of government in the development of BIDs in the UK, and this role will perhaps need to change from encouraging and facilitating the development of individual BIDs, to an attempt to integrate BIDs into wider governance networks, or consider their needs in the introduction of new policy initiatives. With economic and other policy increasingly taking a place-based approach, BIDs can be an important element of this, given their role in the development of effective local economic networks.

\section{References}

Association of Town Centre Management (1997), Town and City Improvement Zones Executive Summary - A Discussion Document, London, ATCM.

Briffault, R. (1999) "A Government for our time? Business Improvement Districts and Urban Governance", Columbia Law Review, Vol. 99, No. 2, pp. 365-477.

Cotterill, E., Grail, J., Mitton, C., Ntounis, N., Parker, C., Quin, S., Smith, D., Steadman, C. and Warnaby, G. (2019), A State-of-the-Art Review of Business Improvement Districts in the UK: Setting the Agenda for Policy, Practice and Research, Manchester, Institute of Place Management/The BID Foundation.

De Magalhães, C. (2014), "Business Improvement Districts in England and the (private?) governance of urban spaces", Environment and Planning C: Government and Policy, Vol. 32, pp. 916-933.

Hair, J. F. Jr., Black, W. C., Babin, B. J., Anderson, R. and Tatham, R. L. (2006), Multivariate Data Analysis (6 $6^{\text {th }}$ Edition), Upper Saddle River, NJ, Pearson-Prentice Hall. 
Hemphill, L., Berry, J. and McGreal, S. (2014), "A financial appraisal of business improvement districts in the UK", Environment and Planning C: Government and Policy, Vol. 32, pp. 680-696.

Hollander, S. (1986), "A rearview mirror might help us drive forward: A call for more historical studies in retailing", Journal of Retailing, Vol. 62, No.1, pp. 7-10.

Hollins, C. (2004), "W(h)ither the high street?", Paper presented at Contemporary Issues in Retail Marketing Conference, Retailing in Town and City Centres: Current Issues, Future Prospects, Manchester, September.

Hoyt, L. (2004), "Collecting private funds for safer public spaces: an empirical examination of the business improvement district concept", Environment and Planning B: Planning and Design, Vol. 31, No. 3, pp. 367-380.

Hoyt, L., and Gopal-Agge, D. (2007), "The business improvement district model: A balanced review of contemporary debates", Geography Compass, Vol. 1, No. 4, pp. 946-958.

Institute of Place Management (2018), An Independent Review of Scottish BIDs, Manchester, Manchester Metropolitan University.

Medway, D., Alexander, A., Bennison, D. and Warnaby, G. (1998), Retailer Involvement in Town Centre Management, Research Report 1998/1. Manchester, Department of Retailing and Marketing, Manchester Metropolitan University.

Medway, D., Alexander, A., Bennison, D. and Warnaby, G. (1999), "Retailers' financial support for town centre management", International Journal of Retail \& Distribution Management, Vol. 27, No. 6, pp. 246-55.

Medway, D., Warnaby, G., Bennison, D. and Alexander, A. (2000), "Reasons for retailers' involvement in town centre management", International Journal of Retail \& Distribution Management, Vol. 28, No. 8, pp. 368-378.

Millington, S., Ntounis, N., Parker, C., and Quin, S. (2015), Multifunctional centres: A sustainable role for town and city centres. Manchester, Institute of Place Management, available at:

https://www.placemanagement.org/research/multifunctional-centres/ (accessed 20 November 2019).

Millington, S., Ntounis, N., Parker, C., Quin, S., Roberts, G. and Steadman, C. (2018), High Street 2030: Achieving Change. Report for MHCLG, available at:

https://www.gov.uk/government/publications/the-high-street-report (accessed 28 October 2019).

Minton, A. (2012). Ground Control: Fear and Happiness in the Twenty-First-Century City. Penguin: London.

New Local Government Network (2003). Speech by Rt Hon Nick Raynsford MP, Minister of State, ODPM to New Local Government Network, available at:

http://www.nlgn.org.uk/public/2003/business-improvement-districts-a-model-for-economicrenewal/ (accessed 6 February 2019).

Parker, C, Ntounis, N, Millington, S, Quin, S, and Castillo-Villar, F. (2017), "Improving the vitality and viability of the UK High Street by 2020: Identifying priorities and a framework for action". Journal of Place Management and Development, Vol. 10, No. 4, pp. 310-348. 
Peel, D. and Lloyd, G. (2008), "Re-generating learning in the public realm: Evidence-based policy making and business improvement districts in the UK", Public Policy and Administration, Vol. 23, No. 2, pp. 189-205.

Peyroux, E., Pütz, R., and Glasze, G. (2012), “Business Improvement Districts (BIDs): the internationalization and contextualization of a 'travelling concept'", European Urban and Regional Studies, Vol. 19, No. 2, pp. 111-120.

Rink, D and Swan, J. (1979), "Product Life Cycle Research: A Literature Review", Journal of Business Research, Vol. 7, No. 3, pp. 219-242.

Shutt, J., De Silva, P. and Muller, T. (1999), Step Change: Town Centre Management Strategies, Regional Development Agencies, and Europe. The Case for a Town Improvement Zone Programme London, ATCM.

Steel, M. and Symes, M. (2005), "The privatisation of public space? The American experience of Business Improvement Districts and their relationship to local governance", Local Government Studies, Vol. 31, No. 3, pp. 321-334.

Travers, T. and Weimar, J. (1996). Business Improvement Districts New York and London. London: City of London Corporation.

Ward, K. (2007), "Business improvement districts: policy origins, mobile policies and urban liveability", Geography Compass, Vol. 1, No. 3, pp. 657-672.

Ward, K. (2011), "Policies in motion and in place: The case of the Business Improvement Districts". In McCann, E. and Ward, K. (Eds.) Mobile Urbanism: Cities and policy-making in a global age, Minnesota University Press, Minneapolis, pp. 71-96.

Warnaby, G. and Medway, D. (2006), “BIDding Goodbye to TCM? Marketing Implications of Changing Urban Management Structures", Paper presented at Academy of Marketing Conference, London

Wells, I. (1991), "Town centre management: a future for the high street", Geographical papers No.109. Reading, University of Reading. 
Figure 1: The five possible stages of a BID

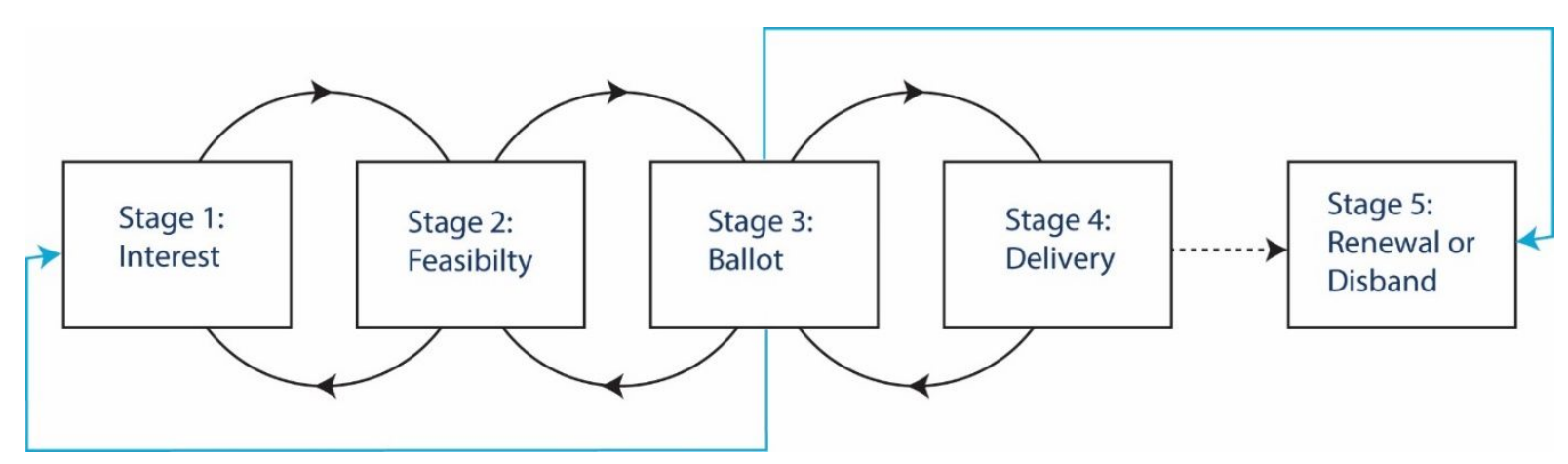


Figure 2: Number of UK BIDs by year

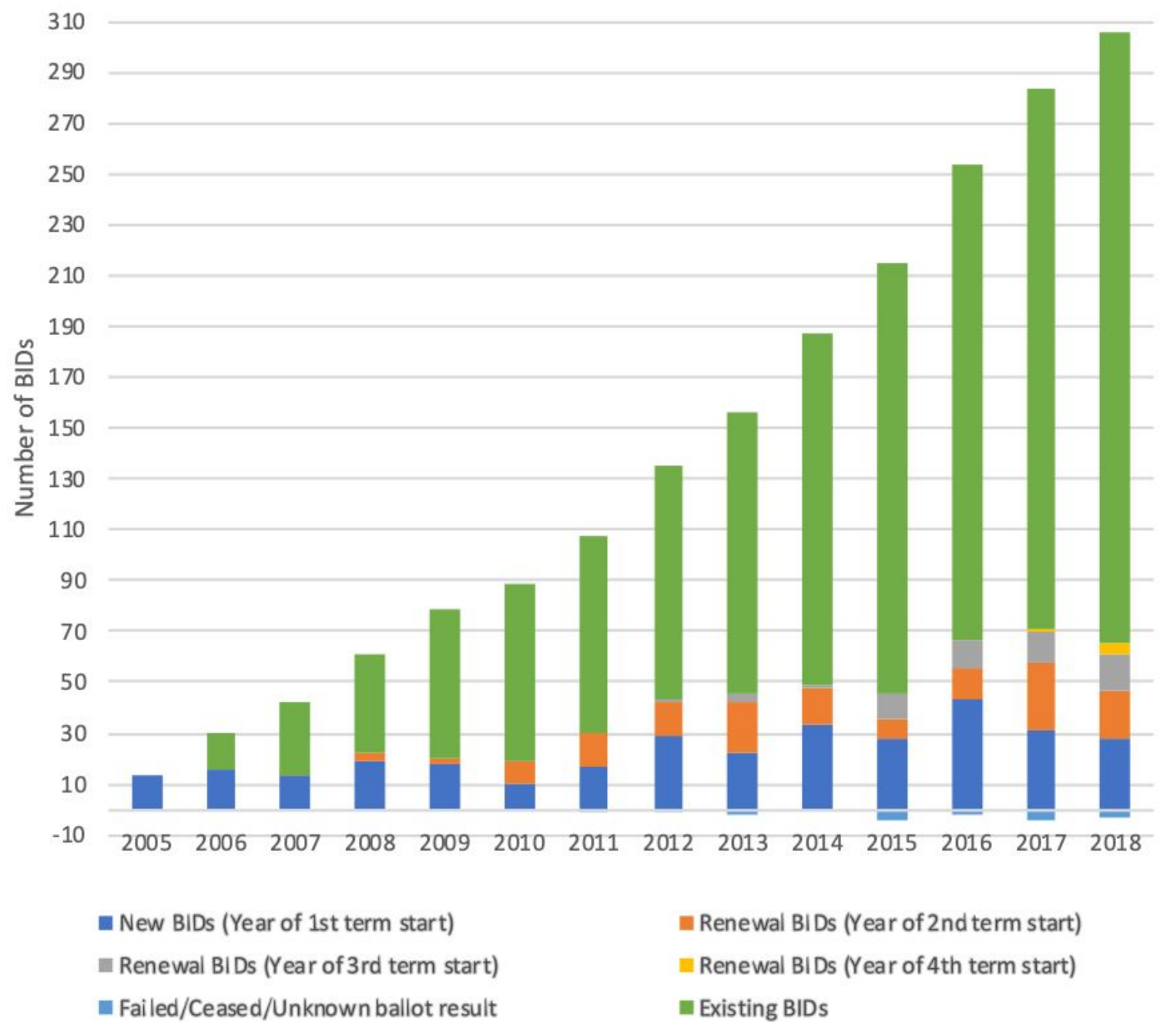


Figure 3: BID Ballot results by term

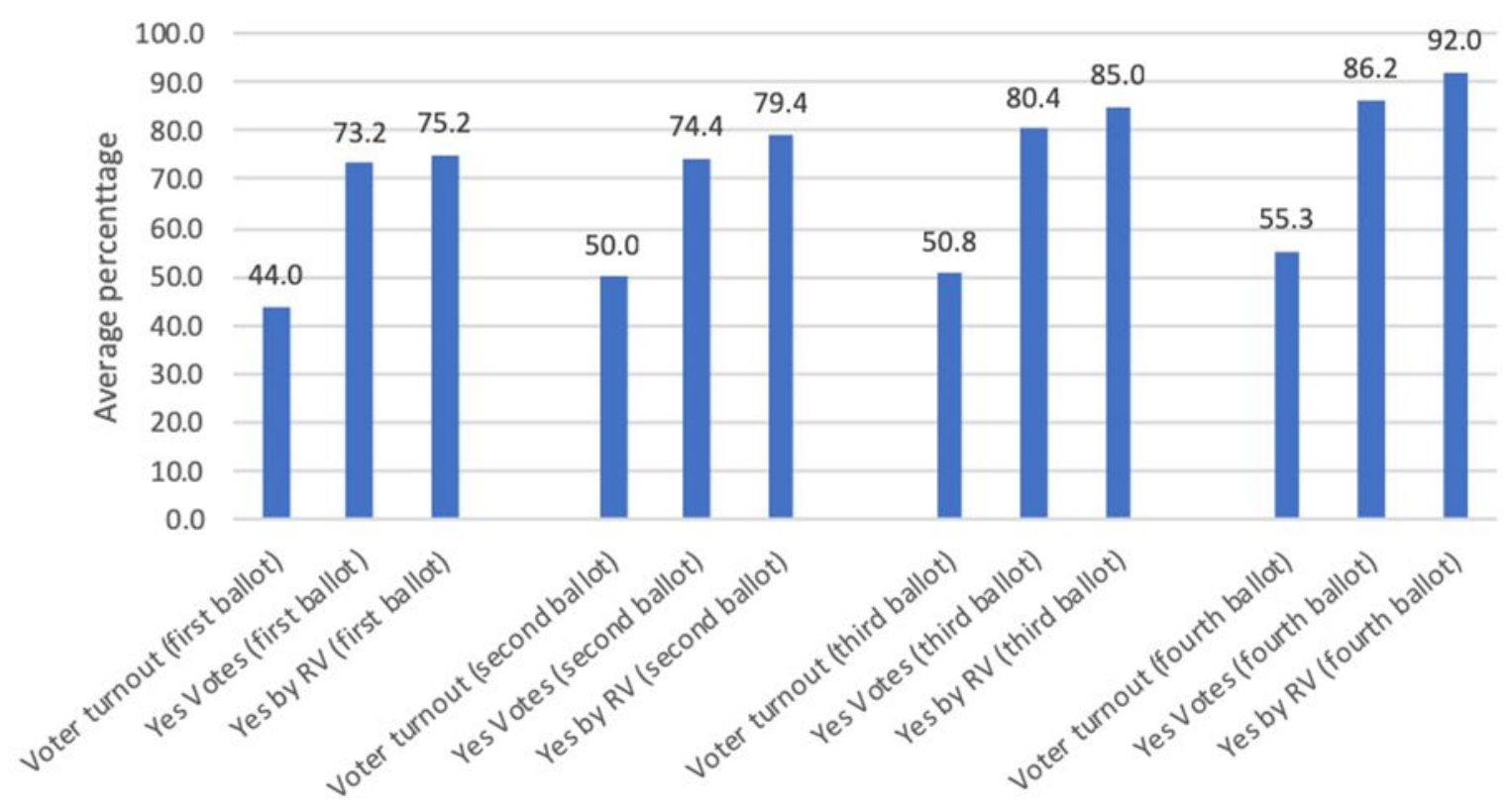


Table 1: Average number of hereditaments and levy income by year of BID establishment

\begin{tabular}{|l|l|l|l|}
\hline Year BID Established & $\begin{array}{l}\text { Number of new BIDs } \\
\text { established }\end{array}$ & $\begin{array}{l}\text { Average Annual BID } \\
\text { Levy (estimated) }\end{array}$ & $\begin{array}{l}\text { Average Number of } \\
\text { Hereditaments }\end{array}$ \\
\hline 2005 & 14 & $£ 629,001.50$ & 517 \\
\hline 2006 & 16 & $£ 294,552.14$ & 377 \\
\hline 2007 & 13 & $£ 311,807.00$ & 363 \\
\hline 2008 & 19 & $£ 358,861.88$ & 583 \\
\hline 2009 & 18 & $£ 302,501.13$ & 496 \\
\hline 2010 & 10 & $£ 387,695.00$ & 438 \\
\hline 2011 & 17 & $£ 309,924.19$ & 448 \\
\hline 2012 & 29 & $£ 332,252.39$ & 441 \\
\hline 2013 & 22 & $£ 330,951.80$ & 331 \\
\hline 2014 & 33 & $£ 222,502.03$ & 408 \\
\hline 2015 & 28 & $£ 385,133.89$ & 567 \\
\hline 2016 & 43 & $£ 369,993.47$ & 481 \\
\hline 2017 & 31 & $£ 391,481.09$ & 466 \\
\hline 2018 & 28 & $£ 349,252.07$ & 394 \\
\hline
\end{tabular}


Table 2: Comparison of ballot results across three terms for all UK BIDs

\begin{tabular}{|l|l|l|l|}
\hline & $\begin{array}{l}\text { Turnout }(\mathrm{n}=38) \\
\text { Mean (s.d.) }\end{array}$ & $\begin{array}{l}\text { Yes Votes by number } \\
\text { of businesses }(\mathrm{n}=54) \\
\text { Mean (s.d.) }\end{array}$ & $\begin{array}{l}\text { Yes by Rateable value } \\
(\mathrm{n}=44) \\
\text { Mean (s.d.) }\end{array}$ \\
\hline $\begin{array}{l}\text { Average BID ballot results } \\
-1^{\text {st }} \text { term }\end{array}$ & $\mathbf{4 6 . 1 ( \mathbf { 9 . 1 } )}$ & $\mathbf{7 6 . 1 ( 9 . 9 )}$ & $\mathbf{7 4 . 5 ( 1 1 . 1 )}$ \\
\hline $\begin{array}{l}\text { Average BID ballot results } \\
-2^{\text {nd }} \text { term }\end{array}$ & $\mathbf{4 9 . 7 ( 9 . 8 )}$ & $\mathbf{7 4 . 9 ( 1 2 . 3 )}$ & $\mathbf{7 8 . 5 ( 1 2 . 1 )}$ \\
\hline $\begin{array}{l}\text { Average BID ballot results } \\
-3^{\text {rd }} \text { term }\end{array}$ & $\mathbf{5 0 . 8 ( 1 0 . 8 )}$ & $\mathbf{8 0 . 7 ( 1 0 . 6 )}$ & $\mathbf{8 4 . 9 ( 9 . 4 )}$ \\
\hline $\mathrm{n}=$ number of BIDs s.d. = standard deviation & \\
\hline
\end{tabular}


Table 3: Descriptors and number of unsuccessful ballots and terminated BIDs

\begin{tabular}{|l|l|}
\hline Descriptors of unsuccessful ballot & Number \\
\hline Unsuccessful at first term ballot & 40 \\
\hline Unsuccessful at first term ballot but BID now established & 13 \\
\hline Unsuccessful at first term ballot re-ballot & 2 \\
\hline $\begin{array}{l}\text { Unsuccessful at first term ballot re-ballot but BID now } \\
\text { established }\end{array}$ & 2 \\
\hline Unsuccessful at second term ballot & 14 \\
\hline Unsuccessful at second term ballot re-ballot & 2 \\
\hline Unsuccessful at second term ballot but BID now re-established & 1 \\
\hline Total unsuccessful ballots & $\mathbf{7 4}$ \\
\hline Descriptors of BID termination & \\
\hline Successful at first term ballot but never established & 3 \\
\hline BID merged & 1 \\
\hline BID disbanded & 10 \\
\hline Total of terminated BIDs & $\mathbf{1 4}$ \\
\hline
\end{tabular}

*Note - a re-ballot defines a ballot that takes place after a failed ballot 